\title{
Review on Factors Affecting Production and Marketing of Spices in Ethiopia
}

\author{
Dagnaygebaw Goshme* Tariku Ayele \\ College of Agricultural Sciences, department of Agricultural Economics, Bulehora University, Ethiopia
}

\begin{abstract}
Spices are produced in different agro-ecologies of Ethiopia that generate income for producers and traders involved in marketing. They are very important cash crops used for food flavor and medication purpose. Even though, their importance the sector is constrained by different factors. The objectives of this review paper are to review factors affecting production of spices, to review factors affecting marketing of spices and to review opportunities of spices production in Ethiopia. Traditional way of farming, absence of seeds and planting materials, high frequency of weeding, high input requirement, high input cost, lack of drying facility, taking long time to dry, shortage of access to credit and extension, different disease and pests, wild animal competition, poor quality of output, absence of proper post harvest handling practices and others are factors affecting production of spices in Ethiopia. Low output price, poor market access and imperfect market information, capital constraints, limited processing of spices, adulteration, mismatch between demand and spices, transportation problems, unlicensed traders, theft, low government support, lack of value addition, price volatility, weak market research and promotion, poor market infrastructure, lack of effective linkage of stakeholders, lack of capacity building, low bargaining power of producers, limited ability of producers to enter in market due to limited time, skill, and resources are some of the factors that affect spices marketing in Ethiopia. Ethiopia is suitable area for spices production due to suitable climate condition and presence of various agro-ecologies, abundant land, cheap labor and favorable policy environment. By reducing different production and marketing constraints the country can boost production and become competitor in the world spices market within a short period of time.
\end{abstract}

Keywords: Spices; constraints; opportunities

DOI: $10.7176 / \mathrm{JBAH} / 9-6-02$

Publication date:March $31^{\text {st }} 2019$

\section{INTRODUCTION}

A spice is a dried seed, fruit, root, bark or vegetative substance used in nutritionally insignificant quantities as a food additive for the purpose of flavoring, and sometimes as a preservative by killing or preventing the growth of harmful bacteria (Masresha, 2010). Spices can be defined as "vegetable products used for flavoring, seasoning and imparting aroma in foods" (FAO, 2005). Ethiopia is a source country for many spice exports, with a long history of spices. The average land covered by spices is approximately 222,700 ha with production reaching 244,000 tons per year. More than 50 spices are produced in Ethiopia, and a total potential for low land spice farming is estimated to be 200,000 hectares (GIT, 2016).

In Ethiopia, the production and use of spices is perhaps the most romantic story of any plant product, legendarily known to go back to the times of Queen of Sheba. Studies showed that, spice crops such as Korarima cardamom, Ethiopian long pepper, Black cumin, Bishop's weed, Coriander, Thyme and Fenugreek are also attached to Ethiopia either as a center of origin or diversity. Spices in Ethiopia are also many things and the role they played could be viewed proportionally to the level of their utilization. For centuries, they have been used as one of the major livelihood and life-giving foods of both the rural and urban populations. Besides, since most of them are labor intensive, small in bulk and so cheap to transport, and of high value per unit, they present a special opportunity to hasten both rural and urban development (Habtewold et. al., 2017).

With 18 major agro-ecological zones and various agro ecological subzones, Ethiopia has a suitable climate for growing more than 146 types of crops and has been producing a number of spices for some time. Out of 109 spices, herbs and aromatic plants shortlisted by International Organizations for the Standardization (ISO), the country produces as many as 50 , out of which 23 are trading as export items. Ethiopia mainly produces ginger, turmeric, cumin, rosemary, cardamom, capsicum, fenugreek, coriander, korarima, Timiz, black pepper, hot pepper, rue, celery and thyme (EIC, 2016).

Spices have major stake in the production system and in the foreign earnings of the country. Spices have great role in transforming farmers as producers for market instead of producing merely for subsistence (Dessalegn, 2015). Ethiopia has become one of the largest consumers of spices in Africa. People use spices to flavor bread, butter, meat, soups, and vegetables. They also use spices to make medicines and perfumes (ITC, 2010). Spices are needed every day in the preparation of the main dishes (Mathewos, 2016).

While there are few spices processing companies operating in the country, there is ample scope for absorbing new entrants. Investors may consider engaging in spices milling, extracting and packing, which are still underinvested in the country. Processed spices products could be further used in the food industry and 
pharmaceutical industry (EIC, 2016).

According to Tiru et.al., (2017), though spices have various utilizations, the emphasis given by research and extension activities are very unsatisfactory. Hence, there is lack of awareness on spice production, processing, storage and marketing among producers. Farmers used their traditional farming practices and usually harvest very low yield. Similarly, the marketing system is not managed through organized efforts. Price of spices is not determined by the demand, supply and price information rather by individual decision. Individual decision making process of the marketing of spice leads to inefficient and ineffective service of the market. Therefore, farmers are not getting expected benefits from this sector. Hence, a radical change should be undertaken in the system to exploit the benefit from these marginalized crops.

The objectives of this review are:

To review factors affecting production of spices in Ethiopia

To review factors affecting marketing of spices in Ethiopia

To review opportunities of spices production in Ethiopia

\section{Factors Affecting Production of Spices in Ethiopia}

According to ACP (2010) as plant species spices have a wide possibility of being cultivated in different agro ecological zones of the country. Except pepper (capsicum annum) spice cultivation is traditional, no improved seed or planting material .The cultivation practice and technique are highly based on knowledge that passed from generation to generation and production level is low. Spices are used as flavoring material, source of essential oil, source of color and cash crop of many smallholders. The cultivation practice in smallholders" farm is fragmented and planted as mixed crop within their main crop land and rain fed.

High frequency of weeding and high input requirements including seed and fertilizers, high cost of production could result in loss of market prices are below the expected level as there are irregularities. In addition, due to lack of facilities for drying, long time is required to dry by using traditional practices that lead to development of fungi during wet weather condition contributing to low market price (Endrias and Asfaw, 2011). Inadequate fertilizer supply, inadequate planting materials, shortage of access to credit and wild animal competition were some factors affecting spices production (Fissiha, 2016).

According to Masresha (2010) lack of high yielding verities, need for improved spice agricultural research in existing and new and locally adaptable varieties that offer opportunities for increased yield, poor quality of final output, weak role of private commercial investors in spices production, irregular supply and variable quality of spices produced from forest and agricultural landscape, lack of proper post harvest handling practices, post harvest wastage/spillage and product quality deterioration, lack of use of appropriate modern technologies in farm management, drying, storage, etc and lack of appropriate spices development strategic interventions were some of factors affecting production of spices.

The challenge of cultivation practice and technique are highly based on knowledge that passed from generation to generation, and the production level is low in need of an efficient spice value chain service delivery mechanism (Vijayalaxmi and Sreepada, 2014).

According to Habtewold et. al., (2017) limited production technologies developed so far have yet not multiplied and popularized to farmers. Disease like Fusarium wilt, blight, Powdery mildew, Downy mildew, Leaf spot, Root rot, Damping off, Rust, Stem gal, Grain mold, and Pest such as Aphids, Mites, Stick-bugs, leafeating caterpillars are constraints that leads to overall reduction in productivity and quality of production system. Melanie and Michael (2011), often small-scale farmers cannot get good seed adapted to their conditions. Poor seed can affect productivity and encourage the spread of disease. Fake seed sold by unscrupulous traders is a major problem in many areas of Africa. Access to finance, equipment and processing expertise are also difficult.

\section{Factors Affecting Marketing of Spices in Ethiopia}

Smallholders are limited in their abilities to enter supply chains and become active players of fostering business relationships and linkages. Limited time, skills and resources may be a constraint on small-scale farmers' ability to become active players in supply chains (FAO, 2011). Low average output price was found to influence marketable supply spices of negatively (Mekdes et.al, 2017). Most common constraints are capital issues, imperfect market information and poor market access (Thijs, 2010).

There is a limited business activity in production, processing and marketing of spices and spice products (ACP, 2010). Adulteration problems, quality problems, capital shortage, demand problem, lack of government support, supply shortage, problem of transport, theft problem and absence of government control on unlicensed traders were determinant factors of spices marketing (Fissiha, 2016).

According to GIT (2016) challenges demanding strategic and routine tasks which call for concerted efforts of all stakeholders from Federal to Regional levels were limitation of extension services to build the capacity of spices producers and value chain players, lack of improved technologies and research services to ensure efficient production and supply of quality spices, lack of modern marketing system to properly guide the production, 
processing and marketing of spices, lack of effective and efficient spiced value chain service delivery mechanism and challenges to channel the spices products to the international market through market promotion and creation of market links.

Keeping spices in store for long in expectation of higher prices, adulteration of inferior varieties with better ones for marketing, poor quality of spices traded due to highly traditional pre and post harvest handling practices; adding water to increase weight and also color/appearance, increasing role of unlicensed brokers in the trading of spices in the market, weak marketing system not stimulating production and marketing based on enforceable quality standards, lack of value addition in terms of major agro processing activities in spices, weak organizational capacity of cooperatives/unions, price volatility due to changes in demand and supply in local and overseas markets, lack of organized market information service to the different actors in the spices farm-tomarket chain, weak market research and promotion in potential overseas markets for natural and processed spices products were marketing constraints of spices (Masresha, 2010).

According to Desalegn (2015) lack of use of appropriate modern technologies, unlicensed traders brokers in the trading of spices, poor training program, lack of organized market information service, lack of proper post harvest handling practices, irregular supply and quality deterioration due to limited commercial investors in spices production, poor access to credit facilities, absence of effective linkage among stakeholders, adulteration of inferior varieties with better ones for marketing, keeping spices in store for long in expectation of higher prices, inadequate processing facilities, price volatility due to changes in demand and supply in local and overseas markets, lack of organized market information service to the different actors in the spices farm to market chain, absence of capacity building like training program, inadequate transport in remote markets specially during wet seasons and challenges from unlicensed traders in spices markets are constraints.

Price setting, weighting and demand are the major factors affecting spices production negatively (Fissiha, 2016). Spices farmers and traders face low prices, difficulty finding markets, lack of capital for transport and extending production, lack of market information and small volumes to sell (Mathewos, 2016).

According to Vijayalaxmi and Sreepada (2014) the presence of inadequate innovate technologies, postharvest handling, spice agricultural research, irregular supply and variable quality of spices produced from forest and agricultural landscape, weak role of private commercial investors in spices production, weak business linkage among stakeholders, absence production and marketing based on enforceable quality standards, lack of value addition in terms of major agro processing activities in spices, price volatility due to changes in demand and supply in local and overseas markets and lack of organized market information service to the different actors in the spices are some of the marketing constraints.

Lack of marketing skills and ability prevents access to potential markets and customers may be lost where there is inability to efficiently deliver the required volumes and quality required. Lack of availability of clean potable water and suitable waste disposal facilities may compromise sanitation and hence product safety (Melanie and Michael, 2011).

Low access to improved inputs, collateral problem to get credit, poor storage facilities and low price of produce were some factors that affect spices marketing (Abay, 2010) Spices marketing is also affected by poor market information system, limited bargaining power of farmers, oligopolistic market structure in the market and also adulteration, natural quality, capital shortage, demand, government support, supply shortage, access to credit, farmers' reluctance to sell, administrative problems, competition with licensed traders, road, theft, competition with licensed and unlicensed traders, storage, telephone services, information flow, health, unstable prices, packaging, broker, bank service and journey (Rehima, 2006).

\section{Opportunities of spices production in Ethiopia}

According to Herms (2015) Spices are one of the traditional high value horticultural crops of Ethiopia. The potential to increase spice production in Ethiopia is very high mainly due to suitable climatic condition, abundant cultivable land and cheap labor, proximity to potential export market and favorable policy environment.

Conducive environmental condition and promising varieties of lowland and highland spices had been identified and released for users. Therefore, it is a very good opportunity to multiply and disseminate the available technologies within the recommended agro-ecologies of the country (Girma et. al., 2015). Spices are traded in national and international level that generates income for producer farmers, traders involved in the market chain and the country as a whole (Mathewos, 2016).

Spices are cultivated in different agro ecological zones of the country. Availability of financial services by banks and micro-credit institutions, Spice crops already widely traded internationally have a high potential for expansion and diversification of export earnings of Ethiopia, Support of policy incentives that enable exporters to implement modern processing techniques and machinery starting from pre harvesting to post harvest processing, an increasing number of buyers/traders/Oleoresin Extraction Companies, Pharmaceutical Manufacturers, choose to buy spices directly from Ethiopia(Vijayalaxmi and Sreepada, 2014).

According to Masresha (2010) to encourage private investment, Ethiopian government has developed a 
package of incentives under Regulations No.84/2003 for investors engaged in new enterprises and expansions, across a range of sectors. These incentives are available both to foreign and domestic investors and the said Regulations doesn't discriminate between a foreign and domestic investor or between foreign investors of different nationalities.

\section{Conclusion and Recommendations}

Ethiopia is a source of different spices with 18 major agro-ecological zones and various agro ecological subzones. Ethiopia has a suitable climate for growing more than 146 types of crops and has been producing a number of spices for some time. The country produces as many as 50, out of which 23 are trading as export items. Spices used to flavor of different foods and to make medicines and perfumes. In the country there is a lack of awareness on spice production, processing, storage and marketing among producers. Farmers used their traditional farming practices and usually harvest very low yield. Production and marketing of spices are affected by various factors.

To improve the production and marketing potential of the country: fulfilling various inputs at remunerative price, introducing new technologies, creating awareness on pre and post harvest spices management, constructing different infrastructures, developing integrated pest and disease management, interventions in the coordination of spices marketing activities and provision of market support services, increasing value addition of spices and follow cost-effective marketing channels, developing good marketing researches and make promotions, increasing government support and others are crucial.

\section{REFERENCES}

Abay, A. 2010. Market chain analysis of red pepper: The case of Bure Woreda, West Gojjam Zone, Amhara National Regional State, Ethiopia. MSc thesis in Agricultural Economics. 91p. Haramaya (Ethiopia): Haramaya University.

ACP(Agricultural Commodities Programme). 2010. Spice Sub-Sector strategy for Ethiopia Submitted to the Government of Ethiopia by the Spice Sector Strategy Coordinating Committee.

Dessalegn Gachena. 2015. Analysis of Factors Determining the Supply of Ethiopian Cardamom Spice (Aframomum corrorima): A Case from Bench Maji Zone of SNNPR, Ethiopia. European Journal of Business and Management, 7 (1): 56-63.

EIC (Ethiopian Investment Commission).2016.Spices sector investment profile summary Ethiopia.

Endrias Geta and Asfaw Kifle.2011.Production, processing and marketing of ginger in Southern Ethiopia. Journal of Horticulture and Forestry Vol. 3(7), pp. 207-213, online http://www.academicjournals.org/jhf ISSN 2006-9782 (C2011 Academic Journals.

FAO(Food and Agriculture Organization). 2005. Herbs, spices and essential oils: post-harvest operations in developing countries, by M. Douglas, J. Heyes \& B. Smallfield, Rome.

FAO(Food and Agriculture Organization). 2011. Spices and herbs for home and market. Rural infrastructure and agro-industries division Food and Agriculture Organization of the United Nations Rome.

Fissiha Gebreyesus. 2016. Determination of Important Factors Affecting Production and Marketing of Korarima (Aframomum Corrorima (Braun) P.C.M. Jansen) in Western Ethiopia. International Journal of Engineering Development and Research (www.ijedr.org)Volume 4, Issue 2 | ISSN: 2321-9939.

Girma Hailemichael, Habtewold Kifelew and Haimanot Mitiku .2015.Spices research achievements, challenges and future prospects in Ethiopia. Academics research journal of agriculture and research.volume 4(1).

GIT (Gatefarms International Trade). 2016. Ethiopian spices \& market potentials, Sebeta, Ethiopia.

Habtewold Kifelew, Demes Fikere, Tewodros Luleseged, Dejene Bekele, Haimanot Mitiku and Wakjira Getachew. 2017. Seed spices production guideline. Ethiopian institute of agricultural research Addis Ababa, Ethiopia.

Herms S. 2015. Business Opportunities Report Spices \#6 in the series written for the "Ethiopian Netherlands business event, Rijswijk, Netherlands".

ITC (International Trade Centre). 2010. Spice Sub-sector Strategy for Ethiopia. Addis Ababa, Ethiopia.

Masresha Yimer. 2010. Market profile on spices in Ethiopia. Addis Ababa, Ethiopia.

Mathewos Agize. 2016. Spice and Medicinal Plants Production and Value Chain Analysis from South-West Ethiopia. Journal of Pharmacy and Alternative Medicine. (www.iiste.org) Vol.10.|ISSN 2222-4807 (online) ISSN 2222-5668.

Mekdes D, Teshale W, Getachew M. 2017.Value Chain Analysis of Red Pepper: The Case of Abeshge District, Guragie Zone, South Ethiopia. Int J Environ Sci Nat Res.; 2(3): 555590. DOI: 10.19080/IJESNR.2017.02.555590.

Melanie Matthews and Michael Jack. 2011. Spices and herbs for home and market. Rural Infrastructure and Agro-Industries Division Food and Agriculture Organization of the United Nations, Rome.

Rehima Mussema. 2006. Analysis of red pepper marketing the case of Alaba and Siltie In SNNPRS of Ethiopia. 
MSc. Thesis Haramaya University.

Thijs Rutgers . 2010. An analysis of supply side constraints on Ethiopian red pepper and paprika capsicum production and export. A global value chain approach, Master thesis International Development Studies, Utrecht University.

Tiru Tesfa, Wondimu Bayu, Arega Gashaw, Hassen Beshir.2017. Spice Production, Marketing, and Utilization in South Wollo, Ethiopia. East African Journal of Sciences. Volume 11 (1) 27-36.

Vijayalaxmi Hegde and Sreepada Hegde.2014.An Economic Overview of Ginger Production in Ethiopia. International Journal of Science and Research. Volume 3 Issue 12. 